\title{
Farm Direct at five years: An early assessment of 0 regon's farm-focused cottage food law
}

\author{
Lauren $\mathrm{G}$ win, ${ }^{\mathrm{a}}{ }^{*}$ Christy Anderson Brekken, ${ }^{\mathrm{b}}$ and Lindsay Trant ${ }^{\mathrm{c}}$ \\ Oregon State University
}

\begin{abstract}
Submitted April 10, 2018 / Revised June 12 and June 29, 2018 / Accepted July 16, 2018 /
Published online September 12, 2018

Citation: G win, L., Brekken, C. A., \& Trant, L. (2018). Farm Direct at five years: An early assessment of O regon's farm-focused cottage food law. Journal of A griculture, F ood Systems, and Community D evelopment, 8(3), 85-104. https:/ / doi.org/ 10.5304/ jafscd.2018.083.005
\end{abstract}

Copyright ( 2018 by the Authors. Published by the Lyson Center for Civic Agriculture and Food Systems. Open access under CC BY license.

\begin{abstract}
In 2011, the O regon legislature passed the Farm Direct Marketing Law (FD ML), which took effect in 2012. The law clarified licensing and food safety requirements for direct-to-consumer sales at farmers markets, farm stands, and similar venues. It also included a "cottage food" provision allowing farms to make and sell certain low-risk, value-added products from farm-grown ingredients, direct to consumer, without a food processor's license. Advocates predicted enhanced small farm viability through new products and revenue streams, market season extension, reduced

a * C orresponding author: Lauren G win, Ph.D ., Center for Small Farms \& Community Food Systems; O regon State University; 131 Crop Science; Corvallis, OR 97331 USA; lauren.gwin@oregonstate.edu

b Christy Anderson Brekken, M.S., J.D ., Applied Economics, Oregon State University; 228 Ballard Extension Hall; Corvallis, OR 97331 USA;

christy.anderson.brekken@oregonstate.edu

c Lindsay Trant, MPP, School of Public Policy, O regon State University, 300 Bexell Hall; Corvallis, OR 97331 USA; lindtrant@gmail.com
\end{abstract}

processing costs, test marketing opportunities, and other avenues. D etractors warned the deregulation would cause outbreaks of foodborne illness. In 2016, the law's fifth year, we explored these predictions and early outcomes. We conducted a focus group with stakeholders and semistructured interviews with two key informants, 18 farmers, and 24 farmers market managers around 0 regon. We found farmers making and selling a variety of value-added products under the FD ML. We found no foodborne illness linked to FD ML products. Interviewees described multiple benefits resulting from the law, many corresponding to predicted benefits. They also described unanticipated benefits at the community level. Interviewees identified barriers and recommended changes related to the law and related education. We discuss the feasibility of these recommendations as well as the long-term potential of the cottage food provision. We end by reflecting on the FD ML as a whole, as it supports O regon's direct market farming sector.

\section{Funding Disclosure}

This study was funded in part by the U.S. D epartment of Agriculture under National Institute for Food and Agriculture grant 2014-68006-21854. 


\section{Keywords}

Farm Direct Marketing, Cottage Food, ValueAdded Food, Small Farms, Local Food, Food Policy, Producer-Processed, Farmers Market, Food Safety, O regon, Direct-to-Consumer Sales

\section{Introduction}

In this paper, we provide an early-stage look at the impact of O regon's Farm Direct Marketing Law (FD ML) five years after it went into effect in 2012. The FD ML was designed to resolve ambiguity about how direct-to-consumer sales of fresh produce should be regulated with regard to food safety. In addition, a cottage food provision created an exemption which allowed farmers to process their own farm-grown produce into low-risk, valueadded foods and sell them direct to consumers without a food processor's license. At the time of its passage, the FD ML was considered an important victory for the direct-market farming sector and a recognition that local food and "knowing your farmer" were valued by O regonians (Brekken, 2012). Those in favor of the law predicted it would not only ease farmer concerns about regulatory ambiguity and burden, but would generate new enterprises and income streams to support overall farm profitability (Bauer, 2011; Brekken, 2012; Lies, 2011; Terry, 2011; Love, 2011). Those who argued against the law predicted increased risk and prevalence of foodborne illness (Brekken, 2012; Lies, 2011; Terry, 2011).

Five years after the law took effect, we interviewed farmers and farmers market managers about their experiences with the FD ML, focusing on the cottage food provision that exempts some producer-processed products from food safety licensing and inspection. We heard from farmers who are making and selling these products that their farming businesses had benefited in a variety of ways, as predicted. We also heard from farmers and farmers market managers about unpredicted ripple effects at the community level. We heard about imperfections in the law and associated rules, as well as a need for additional education and outreach. Regarding food safety concerns, we found no foodborne illness outbreaks that were linked to FDML products.

These findings are useful on three levels. First, while 48 states in the U.S. have some type of cottage food law, there is little direct research on these laws. O ur study fills this gap by providing an early assessment of the perceived benefits and risks of O regon's foray into cottage foods. In this way, we are dipping a toe into an expanding literature on scale, direct marketing, cottage foods, and food safety risk. Second, by identifying both farm- and community-level benefits that may be emerging, our study lays the groundwork for further exploration of how cottage food laws might benefit not just farm viability - the primary focus of the lawbut also rural economies and community food security. Finally, our findings provide initial insights for practitioners and policymakers considering how to support direct marketing farming without risking consumer safety. O ur findings are most relevant to Oregon but have application to any state with or considering cottage food laws.

This paper has five sections. First, we provide summary data on direct to consumer marketing in O regon as important context for the FD ML and then briefly describe the law itself. We then situate the law and our study in the context of existing research, beginning with the legal landscape for small, direct, processed food sales. We then turn to the political and scientific landscape for such sales, centering on the arguments for and against the law at the time of passage. At the end of the introduction, we outline our study and our questions. In the second section, we describe our methods. In the third section, we present our results, structured around our research questions. In the fourth section, we discuss those results by exploring possible next steps for 0 regon's direct marketing farming sector and related research. We conclude in the final section by reflecting on the FD ML as a whole.

\section{Small, Direct, Processed: Balancing Economic Benefits and Food Safety}

$O$ regon has been in the forefront of local and direct-to-consumer (DTC) marketing in the U.S. The 2015 USD A Local Food Marketing Practices Survey found that about $5.5 \%$ of all US farms reported US\$3 billion in DTC sales, with twothirds occurring at on-farm stores and farmers markets (U.S. D epartment of Agriculture National Agricultural Statistics Service [USD A-NASS], 
2016). In Oregon, about $12 \%$ of farms- more than double the national rate- engage in DTC marketing, with sales of over US\$53 million from an estimated 4,252 farms in 2015; this accounts for almost half of the total US\$114.4 million value of local sales in the state, with $81 \%$ of local food farms selling D TC (USD A-NASS, n.d.). Nationally, Oregon ranks 11th in number of farms with local sales, 19th in total value of local sales, and 8th for local sales of fresh produce (O regon D epartment of Agriculture, 2016), even though it ranks 28th in total value of agricultural products sold (USD ANASS, 2017). While we know that approximately 3,000 O regon farms and ranches reported valueadded sales of US\$43.5 million through all local marketing channels, data on the portion of valueadded sales that were sold DTC are not available (USDA-NASS, n.d.). G iven the high interest in local production and consumption, especially for fresh produce, analysts have suggested there is room to expand value-added processing (Sorte \& Rahe, 2015). This can boost both returns to producers and the overall economic impact of agriculture, even at a small, local scale (Alonso, 2011; Alonso \& Northcote, 2013; Miller, 2015; Tarr, 2011).

The strategies to expand DTC and value-added processing and sales could take many forms, including establishing public and private initiatives to form value-added businesses, investing in infrastructure such as commercial kitchens, creating buy-local programs, or offering training and education (Alonso, 2011; Alonso \& Northcote, 2013; Alonso \& O 'Neill, 2011; Tarr, 2011). Cottage food laws are one avenue to lower or reduce regulatory hurdles and the costs of value-added processing, and these laws are now in place in 48 states (Leamy, 2017). O regon's Farm Direct Marketing Law (ORS 616.683) was passed by the O regon Legislature in May 2011 and went into effect January 1, 2012. The Oregon D epartment of Agriculture (OD A) finalized regulations on June 1, 2012 (OAR 603-025-1215 to 603-025-0275). The FD ML, described in detail by Brekken (2012), is specific to DTC sales and has three provisions. The first provision and primary goal was to resolve ambiguity surrounding the state's jurisdiction over "food establishments" by clarifying that the physical spaces for DTC farm sales- farmers market sites, CSA drop sites, farm stands-are excluded from the definition of "food establishments" subject to licensing laws. The farm direct marketer is solely responsible for any regulatory or licensing requirements. The second provision legally distinguished farm direct marketers from "produce peddlers" that primarily buy and resell produce. The third is the cottage foods provision, which deregulated certain low-risk, value-added products processed by farmers for DTC sales. This third provision is the focus of this study.

The L egal L andscape for Small, D irect, Processed F ood Sales

In 2011, the same year the O regon Legislature passed the FD ML, President O bama signed the federal Food Safety Modemization Act (FSMA). The purpose of the FSMA was to establish and expand food safety regulation for produce farmers, food manufacturers, and related supply chain businesses (Boys, Ollinger, \& G eyer, 2015; Miller, 2015; Tarr, 2011). These two laws are very different in that the federal FSMA creates new rules and $O$ regon's FD ML prevents new rules and relaxes existing rules. Y et, they are both shaped by the idea that scale- defined by sales, geographic reach, and the number of links in the supply chain - is linked to the risk of foodborne illness. For FSMA, this is embodied in the fact that farms with less than US $\$ 25,000$ in annual sales are not covered by the Produce Rule (the "de minimis" exemption, i.e., these sales are too minor to merit consideration by the law). This idea that scale is linked to the risk of foodborne illness is also supported by the Tester Amendment to FSMA, which created a "qualified exemption" for produce farmers who sell the majority of all food they produce to consumers, restaurants, or retailers- either within the state or a 275-mile radius- and sell less than US $\$ 500,000$ per year (Boys et al., 2015; Miller, 2015; National Sustainable Agriculture Coalition, 2016). Proponents of the Tester Amendment and O regon's FD ML argued against a "one size fits all" approach to food safety, based not only on food safety risk but on the risk of unnecessarily burdening small farms with compliance costs. These proponents justified their argument by citing the 
closer relationship between producers and consumers geographically and in the supply chain (Boys et al., 2015; Miller, 2015).

The Tester Amendment rests, in part, on the idea that states and localities can better regulate these smaller operations (Miller, 2015). States have historically retained the ability to regulate for the health, safety, and welfare of citizens within their borders; however, they have adopted the U.S. Food \& D rug Administration's (FDA) Food Code, in whole or in part, to harmonize across state lines (US FDA, 2017). To date, all but two states (Hawaii and New Jersey) have amended their food codes by adopting cottage food laws that allow instate sales of low-risk foods prepared in a home kitchen without a food processing license (Leamy, 2017). The justification for cottage food laws is the same as that of the Tester Amendment to FSMA: removing barriers to low-risk value-added processing to expand microenterprise opportunities for small-scale producers and food entrepreneurs - with concomitant benefits to communities - while protecting public health by narrowly defining the exemption and adding labeling requirements (Condra, 2013; Leamy, 2017; Miller, 2015; Tarr, 2011).

There is a wide variation in state cottage food laws; O regon's FD ML is a "middle of the road" law compared to other states in its coverage of the five typical aspects of cottage food laws, see Table 1 (Condra, 2013; Leamy, 2017). The most restrictive aspect of O regon's law, which made it unique, is that it applies only to farmers using their own farm-grown ingredients (O regon Revised Statute $\S 616.683)$.

Table 1. Comparison of Oregon with Other State Cottage Food Laws

\begin{tabular}{|c|c|c|}
\hline Aspect of Law & Oregon Farm Direct Marketing Law (FDML) & Other State Cottage Food Laws \\
\hline Type of food & $\begin{array}{l}\text { Non-potentially hazardous foods (pickles, jams, } \\
\text { dried products, etc.) made by the farmer from } \\
\text { farm-grown produce (except certain nonprincipal } \\
\text { ingredients, e.g., salt, vinegar, pectin, lemon juice, } \\
\text { and sugar) using a recipe from a recognized } \\
\text { process authority such as USDA's Complete Guide } \\
\text { to Home Canning or a recipe pre-approved by a } \\
\text { recognized process authority. }\end{array}$ & $\begin{array}{l}\text { "Non-potentially hazardous" foods that do not } \\
\text { require refrigeration, with a pH level below } 4.6 \text {, } \\
\text { and/ or a low moisture content; some states have } \\
\text { a list of allowed foods. Typically pickles, jam, } \\
\text { dried food, and baked goods are allowed. Only } \\
\text { four states allow potentially hazardous food (e.g., } \\
\text { dairy); Wyoming allows any homemade food } \\
\text { product except red meat. }\end{array}$ \\
\hline Who and where & $\begin{array}{l}\text { Sales must be direct from the producer/ processor } \\
\text { to a consumer at any direct sales venue (e.g., } \\
\text { farmers market). }\end{array}$ & $\begin{array}{l}\text { Sales must be direct to consumer; many states } \\
\text { restrict sales to farmers markets, farm, or home } \\
\text { (or some combination thereof). }\end{array}$ \\
\hline Sales cap & $\begin{array}{l}\text { Gross sales of producer-processed foods must not } \\
\text { exceed US } \$ 20,000 \text { per year. }\end{array}$ & $\begin{array}{l}\text { Half of state laws have no upper limit; the other } \\
\text { half range from US } \$ 5,000 \text { to US } \$ 50,000 \text { in sales } \\
\text { per year. }\end{array}$ \\
\hline $\begin{array}{l}\text { Registration and } \\
\text { licensing }\end{array}$ & $\begin{array}{l}\text { None required, but farmers must keep processing } \\
\text { records (e.g., recipes, pH testing) and are subject } \\
\text { to inspections and licensing by the state } \\
\text { agriculture department if a food safety question } \\
\text { arises. }\end{array}$ & $\begin{array}{l}\text { Twenty states have no registration or require- } \\
\text { ments, and eight have no registration but some } \\
\text { requirements. The remainder have registration } \\
\text { and requirements, } 13 \text { of which have registration } \\
\text { with heavy obligations such as food safety } \\
\text { certification. }\end{array}$ \\
\hline $\begin{array}{l}\text { Labeling } \\
\text { requirements }\end{array}$ & $\begin{array}{l}\text { Products must be labeled with product identity, } \\
\text { name and address of producer, net weight, list of } \\
\text { ingredients (including any major allergens), and } \\
\text { "THIS PRODUCT IS HOMEMADE AND IS NOT } \\
\text { PREPARED IN AN INSPECTED FOOD ESTABLISH- } \\
\text { MENT" and "NOT FOR RESALE" in all capital, } \\
\text { boldface type no less than } 1 / 8 \text { " (3.175 mm). }\end{array}$ & $\begin{array}{l}\text { Forty-six out of } 48 \text { states require labeling such as } \\
\text { the common name of the food, name of the } \\
\text { producer, contact information for the producer, } \\
\text { information on weight or quantity of food being } \\
\text { sold, and ingredients. Two states have no } \\
\text { labeling requirements. }\end{array}$ \\
\hline
\end{tabular}

Source: Leamy, 2017. 
The Political and Scientific $L$ andscape for Small, D irect, Processed F ood Sales

The FD ML passed with strong support, with only 16 of 90 legislators opposing (The O regonian, n.d.). However, getting there was not easy, largely because of debate about the cottage food provision. In this section, we describe the political arguments and scientific evidence in favor of cottage food laws in general and in favor of the FD ML in particular. We also describe the political arguments and scientific evidence against them. We conclude with a summary of the tradeoffs faced by policy makers and then introduce our research questions.

A rguments and evidenœ in favor of oottage food laws The primary argument for the FD ML cottage food provision, echoed in the literature, was that it would support farm economic viability through multiple, interlinked mechanisms: removing ambiguity about on-farm post-harvest handling of direct-marketed foods; reducing fixed and per-unit processing costs; creating new products and new income streams; turning excess or unsold harvest into marketable product; extending the market season with shelf-stable products; test marketing before investing in infrastructure; and processing quantities too small for a co-packer to handle (Bauer, 2011; Brekken, 2012; Lies 2011; Love, 2011; Terry, 2011). Research on food safety regulation impacts on small food businesses and value-added processing indicates that increasing fees and requirements can add costs and barriers that keep some small-scale firms out of the market, while value-added processing has benefits such as using produce that would otherwise go to waste (Alonso, 2011; Alonso \& O'Neill, 2011; Alonso \& Northcote, 2013; Antle, 2000; D eLind \& Howard, 2008; Worosz, Knight, Harris, \& Conner, 2008). Conversely, others have argued that regulations can provide operational benefits for small food processors (Buckley, 2015; Fairman \& Y app, 2005; Mensah \& Julien, 2011). In a 2017 report, a survey of U.S. cottage food producers finds that the cost of constructing or renting a commercial kitchen is a barrier to starting a valueadded business (Leamy, 2017); other research has pointed to the lack of commercial kitchens in rural areas (Alonso, 2011; Alonso \& O 'Neill, 2011;
Leamy, 2017; Tarr, 2011). A review of states that require registration of cottage food businesses finds that thousands of new businesses have been formed since the laws were passed (Leamy, 2017).

An auxiliary argument in favor was that the provision would reduce the regulatory burden on the state without taking away regulatory oversight altogether. By exempting small-scale, non-potentially hazardous products, the public sector could focus limited enforcement resources on high-risk, high-volume foods that are more likely to sicken many people (Brekken, 2012; Leamy, 2017; Love, 2011; Terry, 2011). This is a general argument in the literature on scale and food safety regulation (e.g., DeLind \& Howard 2008).

Benefits to local economies and food security are also prevalent arguments in support of cottage food laws and increasing value-added processing or D TC sales in general (Alonso, 2011; Alonso \& Northcote, 2013; Alonso \& O 'Neill, 2011; Miller, 2015; Tarr, 2011). These arguments were not at the forefront during the debate on the FD ML; however, they emerged in O regon in 2015 during debate of the state's second cottage food law, the Home Baking Bill (SB320) (Leamy, 2017; Thomas, 2015). This law allows the unlicensed production and DTC sale of baked goods, candies, and confections by any home baker from any ingredients, not just farmers using their own farm-grown produce ( $G$ win, 2018). Studies in O regon and elsewhere have identified economic impact related to local food, though not specifically for DTC sales or cottage food (Rahe, Van Dis, Weiland, \& G win, 2017). As Jablonski, Hendrickson, Vogel, and Schmit (2017) explain in a recent review article, local food systems can generate rural economic development, but social, cultural, physical, politi$\mathrm{cal}$, and other forms of wealth that contribute to community well-being are also meaningful outcomes that deserve more attention. For example, researchers have suggested that farmers markets and other DTC venues can increase healthy food access in rural communities (Johnson et al., 2014). However, there is still little empirical evidence of these claims, especially related to direct sales of processed foods. O ur study begins to fill this research gap. 
A rguments and evidence against cottage food laws

The argument made against the cottage food provision in the FD ML was that reduced regulatory scrutiny would allow unsanitary production practices that in turn would cause foodborne illness outbreaks, even for non-potentially hazardous products sold in small quantities. The Northwest Food Processors Association and the O regon Farm Bureau opposed it on these grounds (Bauer, 2011; Leamy, 2017; Lies, 2011; Terry, 2011). Empirical research on actual food safety outcomes resulting from small-scale farms, direct marketing, or cottage food laws is limited but emerging (Miller, 2015; Y oung, Thaivalappil, Reimer, \& Greig, 2017). A 2017 meta-analysis of food safety at farmers markets in the U.S. and Canada found not only that foodborne illness resulting from farmers market sales is rare but also that many studies have only investigated farmer, market manager, and regulator practices, knowledge, or experience related to food safety protocols rather than outcomes (Y oung et al., 2017). Research on scale and food safety concludes that different scales generate different food safety challenges; thus, regulation and education must emphasize scaleappropriate interventions (Buckley, 2015; Clayton, Griffith, Price, \& Peters, 2002; D eLind \& Howard, 2008; Fairman \& Yapp, 2005; Parker, D eNiro, Ivey, \& D oohan, 2016; Yapp \& Fairman, 2006). Only one study was identified that specifically focused on cottage food laws, in which surveyed state regulatory officials and food safety educators nationwide reported their perceptions of existing knowledge and capital gaps of cottage food producers rather than actual outcomes (Harrison, Critzer, \& Harrison, 2016). O ur study, by exploring the actual food safety outcomes related to a specific cottage food law, adds to the currently limited empirical research on this topic.

O ne challenge in the design of cottage food laws is that the restrictions on products, locations, ingredients, recipes, sales caps, and labelling can make them operationally unfeasible, such that users struggle to follow the rules (Brekken, 2012; Leamy, 2017). This could result in fewer eligible producers taking advantage of the opportunity to engage in value-added sales, or it could lead to violations of the law that undermine the credibility of FD ML products. After the law passed, advocates were concerned that the FD ML cottage food provision was too narrow, limiting who could benefit, too complex, and too difficult to communicate and follow (Brekken, 2012). Another concern was that farmers markets might require vendors to have liability insurance at a level that would cost more than the profits made from value-added or DTC sales (e.g., Boys et al., 2015). Existing studies of the operational feasibility of cottage food laws focus on how the laws are written. O ur study provides an empirical look at this issue for users, in practice.

Policy tradeoffs and continuing debate about cottage food laws

Food safety regulation that requires licensing, inspections, and labeling is generally justified as a way to ensure the visibility, reliability, accountability, and traceability of foods sold to the public (Stearns, 2010). The literature on farm direct marketing in general- and cottage food laws in particular-articulates the inherent tension between reducing food safety regulation to expand food and farm entrepreneurship and the public interest in food safety (Boys et al., 2015; Brekken, 2012; Condra, 2013; Leamy, 2017; Miller, 2015; Tarr, 2011). O verall, the empirical research indicates that small firms and direct sales of fresh or processed foods can create foodborne illness, but the total risk of harm to the public is small due to the design of cottage food laws and the small number of processors and consumers (Brekken, 2012; Condra, 2013; Leamy, 2017; Y oung et al., 2017). Oregon and 47 other states have weighed the benefits to individual farmers, entrepreneurs, and their communities against the increased risk of foodborne illness and have passed cottage food laws.

\section{Study Purpose and Research Questions}

To provide insights into the actual outcomes of O regon's FD ML provision, we conducted an earlystage assessment in 2016 to probe whether any of the predicted outcomes- positive and negativeof the FD ML's cottage food provision had emerged in the law's first five years. We expected that it was still fairly early to see extensive evidence of any of these outcomes. We therefore designed 
our assessment as exploratory and open-ended, not for statistical generalization, with the goal of laying the groundwork for a more comprehensive future study when more time had passed (Buckley, 2015). We structured our study around five specific questions:

1. Are farmers making and selling products under this provision, and if so, which products?

2. Has the FD ML resulted in any food safety outbreaks?

3. How has the FD ML benefitted farmers, the direct marketing sector, and communities?

4. What barriers do farmers face when using the FD ML?

5. How could the law be improved?

On a practical level, these questions were designed to provide policymakers and stakeholders with information about how this law is working in practice. We had been asked these questions not only in O regon but by local food organizations in other states with interest in similar opportunities for farmers in their states. O $\mathrm{n}$ a broader level, these questions were designed to allow us to contribute to research on cottage food laws and direct sales of processed food, as noted above, by describing actual outcomes of a specific law.

\section{Study Methods}

For this exploratory, qualitative study, we began with a focus group and then conducted semistructured interviews with farmers, farmers market managers, and two additional key informants (Bernard, 2011). Farmers markets are only one possible market channel for producer-processed products, but starting at markets gave us access to many farmers at one time and allowed us to observe the different products labelled as being processed and sold under the FD ML. Before beginning the study, we received approval from our university's institutional review board.

F ocus $G$ roup and Key Informant Interviews

We began this research project by convening a two-hour focus group of five people active during the legislative and regulatory process that led to the FD ML (Bernard, 2011). We asked a series of openended questions to elicit their opinions and experiences regarding how the law has affected 0 regon farmers and local food systems. We used their answers to refine our research questions, our research design, and our interview questions. We then conducted semi-structured interviews with an ODA employee involved with implementation and an O regon legislator who provided key support for the bill during passage. We asked open-ended questions relevant to those specific roles.

\section{Farmer and M ark et M anager Interviews}

We conducted 42 semistructured interviews with farmers $(\mathrm{n}=18)$ and farmers market managers $(n=24)$. We aimed for a geographically diverse set of interviews around O regon, using the 2016 map of O regon State University (O SU) Extension regions (Figure 1) as a sampling matrix. Most of our interviewees were located in regions that support most of O regon's farmers markets: the
Figure 1. Oregon State University Extension Regions (as of 2016)

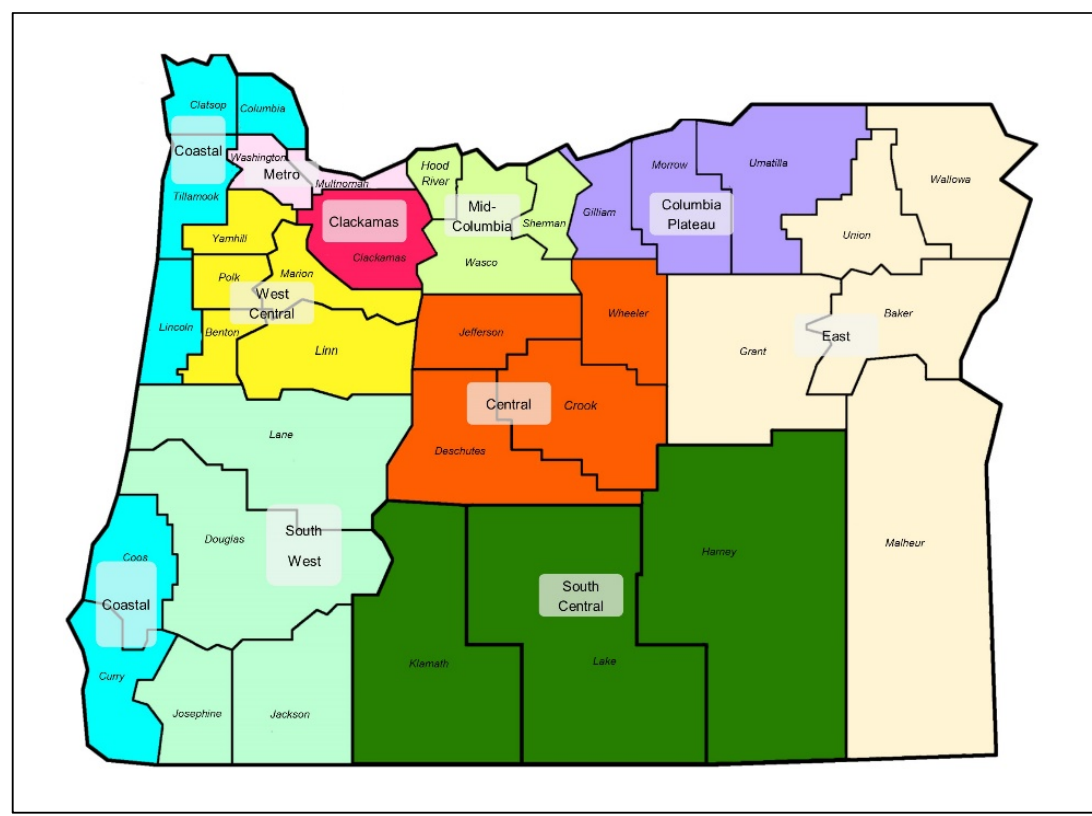


population centers of the Portland Metropolitan region (Metro), Willamette Valley (Clackamas, West Central), Coastal Oregon, and South West Oregon. However, we also interviewed farmers and market managers in less populous areas, including the Columbia Basin, Eastern O regon, and Central and South Central Oregon. Table 2 lists attempted and successful interviews by Extension region.

To recruit farmers, we visited 20 farmers markets in eight of the ten regions (except Columbia Plateau and South Central), located farmers selling FD ML-labeled products, and asked them to participate in our study. In all, we contacted 30 farmers, and 18 chose to participate. To recruit market managers, we began with the O regon Farmers Market Association's market directory. This directory is voluntary, but it is still the most comprehensive public list of markets and managers. We contacted every manager on the list by phone, email, or both, except in regions where we already had sufficient interviews. In all, we contacted 66 managers, and 24 chose to participate. We also found some farmers and market managers through a purposive snowball method from other farmer and market manager interviews (Bernard, 2011).

We developed an interview guide with openended questions corresponding to four of our five research questions (Bernard, 2011); we answered the foodborne illness question separately, as described below. Interview questions were openended to allow unexpected themes and patterns to emerge. We did not ask about specific predicted benefits but instead asked about benefits in general.

We conducted nearly all of the interviews
Table 2. Market Manager and Farmer Interviews by Oregon State University

\begin{tabular}{lcccc}
\hline & \multicolumn{2}{c}{ Market Managers } & \multicolumn{2}{c}{ Farmers } \\
\hline Contacted & Interviewed & Contacted & Interviewed \\
\hline More populous regions with more farmers markets & 18 & 6 & 1 & 1 \\
\hline Metro & 7 & 2 & 3 & 2 \\
\hline Clackamas & 11 & 3 & 12 & 6 \\
\hline West Central & 6 & 3 & 7 & 5 \\
\hline South West & 14 & 5 & 2 & 1 \\
\hline Coastal & 2 & 1 & 1 & 0 \\
\hline Less populous regions with fewer farmers markets & 0 & 0 & 0 \\
\hline Mid-Columbia & 2 & 2 & 4 & 3 \\
\hline Columbia Plateau & 4 & 1 & 0 & 0 \\
\hline Eastern & 1 & 1 & 0 & 0 \\
\hline South Central & 1 & 24 & 30 & 18 \\
\hline Central & 66 & & & \\
\hline Total & & 24 & & \\
\hline
\end{tabular}

during the 2016 market season (July to September); most were by phone, five were in person, and two were by email. Interviews lasted between 30 and 60 minutes. We transcribed the interviews and coded them using the qualitative analysis software, Dedoose, using open, axial, and selective coding methods, developing codes in a constant comparative process (Robson 2011). We did not start with pre-determined codes- e.g., codes for the specific arguments for and against the law.

Limitations

As noted above, our qualitative assessment is exploratory and not designed for statistical generalization. We do not claim to be able to estimate what percentage of direct-market farmers in O regon use this law in all direct-to-consumer venues. O ur purposive, exploratory approach was more appropriate than attempting a representative sample (e.g., through a survey) for two reasons. First, there is no defined population to sample: the FD ML provides an exemption from licensing, and no list of users exists. Second, our goal was to learn if and how the law was being used and to what effect, not to measure the number of farmers, 
products, or sales. O ur study provides the first glimpse of the impacts of this policy.

Food Safety 0 utbreak D ata

Based on guidance we received from the 0 regon Health Authority (OHA) and ODA, we examined the Center for Disease Control (CDC) database of foodborne illnesses to learn of any outbreaks attributable to FD ML-allowed products since the law's passage. Oregon has a strong history of investigating and reporting foodborne illness to the U.S. Center for D isease Control (CDC) and is one of six states designated as a CDC Integrated Food Safety Center of Excellence (Center for Science in the Public Interest, 2015; OHA, n.d.). O regon's system requires clinicians and laboratories who treat and test presumptive and confirmed foodborne illness cases to report to their county health departments, which then investigate and report to the OHA. OHA then investigates and reports outbreak data from all counties to the CD C FoodNet (Center for Science in the Public Interest, 2015; O HA, n.d.). The CDC database then reports all known foodbome illness outbreaks and details (if known) including the month and year, state, genus species and serotype or genotype, etiology status, location of preparation, number of illnesses, hospitalizations and deaths, the food product, and the contaminated ingredient. This is the most complete foodborne illness data in the United States. We reviewed CD C data on foodborne illness in Oregon from 2012 to 2016, the most recent data available (CD C, 2016; search results on file with authors). We analyzed this data to find sources that could be FD ML foods through the location of preparation and the food product information.

\section{Results}

We present our results for each of our research questions, first listing the themes that emerged for each and then describing each theme based on interviewees' experiences. In summary, farmers around the state are using the FD ML to sell valueadded foods made in their home kitchens. The main argument against the FD ML does not appear to have materialized: we found no evidence of widespread or acute foodborne illness resulting from FD ML foods. The farmers and market managers we interviewed reported most of the anticipated benefits and some additional, less expected benefits. They also described barriers to using FD ML and made suggestions for improving the law.

A re farmers making and selling products under this provision, and if $\mathrm{so}$, which products?

At 18 of the 20 markets we visited, farmers were selling value-added products under FD ML. These products were clearly identifiable by their required labels. Several market managers said they had seen a steady increase over the years since the law was passed in the number of farmers using it and the number and variety of products. Managers are accurate reporters on this point because they collect and keep vendor records, including what products vendors are selling. The farmers we interviewed were making and selling a wide variety of products, including jams, jellies, and preserves; canned fruit and applesauce; pickled vegetables; relishes; sauerkraut; dried fruit; seasonings and seasoning salts; dried herbs and herbal teas; kale chips; soup mixes; kimchi; hot sauces; salsas; honey; granola; and homemade vinegars. Some farmers had one or two products, while others had more than a dozen.

H as FD M L resulted in any food safety outbreaks? We found no foodborne illness outbreaks that could be definitively traced to FD ML foods. We found three instances in the "fair, festival, other temp or mobile services" category that were traced to catering or restaurants, neither of which is allowed to source and serve FD ML foods. We found no outbreaks listed in the "farm/ dairy" preparation site category. All illness outbreaks from food sources that could possibly have been a FD ML product (e.g., "pickles," "berries," "salsa," "sauce," etc.) were traced to production at private residences, restaurants, or banquet facilities (CD C, 2016; search results on file with authors).

While the lack of cases in the CDC database does not unequivocally prove that FD ML foods have not caused any foodborne illness, it is reasonably strong evidence that FD ML foods have not caused a reportable outbreak. While not all 
foodborne illnesses are reported and only about one-third of Oregon's reported cases identified both a pathogen and food source from 2003 to $2012,45 \%$ of those outbreaks affected between 2 and 10 people. This demonstrates 0 regon's investigation of small outbreaks, even from limited food sources (Center for Science in the Public Interest, 2015). It is also worth repeating that FD ML does not undercut the ODA's authority to change or add rules as needed if foodborne illnesses become a problem. As a farmer who participated in our initial group discussion said, "If there is an issue, I believe the statute and rules give [ODA] the authority to deal with an unsanitary situation." In an interview with an OD A food safety specialist, we learned that ODA does not keep any formal records of illnesses related to the FD ML, but that there were no known illness complaints associated with the FD ML. Furthermore, the person explained, OD A does receive questions and complaints- such as requests for clarification of the rules- primarily from farm direct marketers who are monitoring other farm direct marketers. This creates a form of self-monitoring in the sector (W. Fargo, personal communication, April 9, 2018).

H ow has the FD M L benefitted farmers, the direct mark eting sector, and communities?

We asked farmers and market managers what the FD ML has meant for them and their businesses, specifically the cottage foods provision.
Unprompted, responses clustered into seven general themes (Table 3) and included many benefits anticipated by the advocates of the FD ML (described above), specifically those related to the economic viability of small farms. Farmers and market managers also identified community-level benefits that were not anticipated at the time of passage. We discuss each of the reported benefits, first discussing the anticipated benefits mentioned most, then the unanticipated benefits.

Create $\mathrm{N}$ ew, Supplemental Inome Streams (A nticipated)

As noted earlier, one of the primary arguments for the passage of FD ML was that it would boost farm income by creating new market opportunities and new, supplemental revenue streams. We learned from our interviews that this has indeed happened. It was one of the top two benefits that emerged from the interviews; it was raised by 10 farmers and three market managers. For example, a market manager observed that, in the years since the passage of FD ML, her vendors had become "more creative about the number of products they can bring to market, which ultimately puts more money in their pocket." A farmer in Southern O regon, who sold about US $\$ 10,000$ of FD ML products annually, said this was, "a huge boon to our farm because, boy, it would be difficult at [US] $\$ 10,000$ to afford the flat infrastructure cost it would take to have a facility, but you know a small amount like

Table 3. Benefits Related to Using the Farm Direct Marketing Law (FDML) $(\mathrm{N}=42)$

\begin{tabular}{|c|c|c|c|}
\hline BENEFIT & $\begin{array}{l}\text { Farmer } \\
(n=18)\end{array}$ & $\begin{array}{l}\text { Market Manager } \\
(\mathrm{n}=24)\end{array}$ & Total \\
\hline \multicolumn{4}{|l|}{ Anticipated } \\
\hline Create new, supplemental income streams & $10(56 \%)$ & $3(13 \%)$ & $13(31 \%)$ \\
\hline Turn excess harvest and seconds into revenue, reduce waste and cost & $9(50 \%)$ & $4(17 \%)$ & $13(31 \%)$ \\
\hline Add variety to market stall & $5(28 \%)$ & $2(8 \%)$ & $7(17 \%)$ \\
\hline Test marketing, batches too small to co-pack, reduced per-unit cost & $5(28 \%)$ & $0(0 \%)$ & $5(12 \%)$ \\
\hline Extend marketing season beyond availability of fresh produce & $4(22 \%)$ & $1(4 \%)$ & $5(12 \%)$ \\
\hline \multicolumn{4}{|l|}{ Unanticipated } \\
\hline Benefits to farms and communities in isolated rural regions & $5(28 \%)$ & $1(4 \%)$ & $6(14 \%)$ \\
\hline Food security & $2(11 \%)$ & $2(8 \%)$ & $4(10 \%)$ \\
\hline
\end{tabular}


[US]\$10,000 really helps out our farm for the year.”

Turn $\mathrm{E} x$ cess $\mathrm{H}$ arvest and Seconds into Revenue and Reduce W aste (A nticipated)

The opportunity to turn surplus harvest, unsold fresh products, and seconds into saleable, valueadded products was the other benefit most often mentioned. O ne farmer said that this option, "helps me guard against a lot of product loss, like stuff that I would have had to either been composting or it would have been more jam than I could have used personally." Another farmer uses otherwise unsalable culls from one crop in a recipe: "If I have a byproduct from, let's say, planting garlic, I can use my small bulbs or small cloves and make an array of different flavored pickles," for which, he added, he can get a higher price. Similarly, he uses his B-grade carrots and garlic in his kimchi.

Market managers also spoke to the value of using unsold produce. O ne manager explained, "It's really good for the farmers... let's say they have a bunch of strawberries and they can't sell them all because it rained or something happened and people couldn't come [to the market]. They can go home and make jam with it. Otherwise, they'd have to throw it in the compost pile... it's a money loss." While compost has economic value to the farm, both farmers and market managers equate product loss not only with financial loss but with unnecessary food waste. And although converting perishable produce into non-perishable value-added products has additional costsincluding time, energy and materials- those perunit costs are reduced significantly due to the FDML.

A dd V ariety to M ark et Stall (A nticipated) An additional benefit of adding new product lines is variety itself. That is, the new products fill out the market booth, and that variety attracts different customers. As one farmer said, "It's a guaranteed seller... Y ou can have a day where the market is flat and you hardly sell any vegetables and so it sort of helps balance that." Similarly, a market manager said, "When you have a lot at your booth, maybe a lot of produce that day, getting out several cases of canned things or dried things makes your booth look full. That's really helpful, because I've noticed that people tend to buy in booths that look more abundant than other booths... Humans gravitate toward abundance."

Farmers also use value-added products as a lure. A market manager described a rancher who primarily sells meat but also a small amount of cucumbers and tomatoes. A frozen cut of meat that costs US\$10 per pound can seem expensive, but "if they put out a small jar of pickles that costs [US]\$5, people will buy the pickles before they buy the meat, and I think that helps them build trust in that farmer." The manager reported that, for this rancher, that customer had come back to buy meat and was now a regular customer. As we discuss in more depth later, booths with preserved foods may also attract tourists.

E x tend the Mark eting Season (A nticipated)

Processed products can extend a farm's marketing season into times when fresh product is less abundant, both supplementing income and smoothing out cash flow. A farmer explained that they now have something to sell at the early season and late fall markets, as well as a winter market. $\mathrm{He}$ described, "It keeps our cash flow more stable... it's really helped to increase our shoulder season and create a more stable season for the farm altogether."

Farmers are also able to market highly seasonal crops over a longer period. A tree fruit and berry farmer remarked, "It gave us a chance to give our crops shelf life... We need to be able to sell them for more than a few weeks of the year." A third farmer noted that while her marketing season was not longer, it kicked off more successfully with FD ML products on the table: "It doesn't change the number of markets we attend but makes our table look much more full in the early weeks of the market."

Reduce Financial Risk through T est Mark eting (A nticipated)

O ur fifth theme combined three predicted benefits of FD ML: that producers could (a) test market products in small batches before investing in expensive licensing and infrastructure, or (b) process batches that are too small for co- 
packing, (c) at a lower per-unit cost. Test marketing not only encourages small business developmentand potential job creation if the business scales up- but also prevents significant financial loss for a farm if the product idea fails. While using a copacker can be a successful and low-risk way to develop and test-market new products (G win \& McCann, 2017), our interviews confirmed that many farmers in O regon are not located near a copacker or simply do not have enough raw product to meet a co-packer's minimum batch size. FD ML allows farms to test-market, in very small batches, from their own kitchens, often at a per-unit cost lower than a co-packer would charge.

Test marketing serves several purposes, often simultaneously. First, a farm that sells FD ML products can find out what customers like, allowing them to plan production and processing in future years. Then they can scale up or shift production and processing to focus on the few products that are top-sellers. At least four farmers we interviewed were using FD ML with this in mind. "It gave us an opportunity to see what would work for us," a farmer said. Another explained that "there were some varieties of fruit spreads that we did that didn't sell as well as others, so it was really helpful to be able to not have to invest all our money [into the costs of a licensed facility]... that way we were able to branch out starting the second and third year knowing what we needed to grow more of."

If successful, the scaling up process can take farms above the FD ML sales limit. A mid-scale, diversified produce farm selling mostly fresh produce into both direct and wholesale markets had recently added a small retail store on the farm with a wide variety of FD ML products. The farmers have no intention of maintaining such a diverse product line: "We are trying things out to see what consumers respond to," said one of the farm owners. Each year, they plan to identify four top-selling products for scaled-up production in a licensed commercial kitchen.

Several farmers also made it clear that testmarketing on a small scale was their path to scaling up to larger volumes and wholesale marketing. "This is sort of a foothold for us to move in that direction," one farmer said, "so we can start to develop those [products], get good recipes, test our marketing, and then step it up eventually. Then we can do wholesale marketing." A market manager shared a story about a farm selling dried beans and grains, grown in a region not normally known for those products: "They were having trouble with marketing, but [FD ML] made it feasible to have a little bit of those products in markets and get some acceptance of locally raised grains." The farm has since expanded its production volume and market channels to include wholesale customers, outside of the FD ML exemption. In a variation on this theme, another farmer envisions a scaled-up valueadded food business that would source from her and other farmers who want to stay small. She explained, "O ur biggest product by far is hot sauce, and it's small, 500 bottles last year, [US]\$8 or [US]\$9 per bottle. O ur hot sauce is really popular ... if it's really that good, someone may want to scale that up."

However, not all farms are looking to grow. Some farmers said FD ML allows them to stay small and not outstrip the capacity of both their farm and their community. A small-scale farmer in a rural area said that he did not expect to exceed the US\$20,000 limit. He explained, "I would have to have [on-farm] help, and I would probably have to be charging a lot more for my stuff, and people in this community and our area cannot afford a lot of the higher priced stuff."

Benefits to Farms and Communities in Isolated Rural Regions (U nanticipated)

O ur research suggests that FD ML may have particular significance for rural Oregon, which has a low population density, lower per capita income than urban areas of the state, has experienced a loss of rural grocery stores and access to fresh foods, and has a less favorable climate for growing fresh produce (Lurie \& Brekken, 2017). A farmer in Eastern O regon explained, "That's how everything is, this side of the state versus that side with agriculture... it's just so different here than it is over there." Farmers and market managers spoke to this in a variety of ways, and three stood out in particular: FD ML has alleviated a lack of commercial kitchens, fits well within agritourism, and has the potential to generate community-level benefits beyond the farm. 
L ack of commercial kitchens

Small food processors often start by renting time in a licensed commercial kitchen, but isolated rural areas often lack this infrastructure for local businesses. A farmer who now sells a popular line of fermented products and pickles said that FD ML made legal what was practically impossible before. He was already making the products for his personal use, but lacked the capital to build his own licensed kitchen and was not sure he could produce enough to support such an investment. His rural community, and the surrounding area, had no commercial kitchen. He explained, "This is one of the least prosperous parts of Western Oregon... It's miles away from anything and there's no economy. ... The school closed down, the tavern closed down, the store closed, everything closed down. This is rural O regon." In his experience, FD ML had created space to alleviate some of these challenges, though he hoped more would be done.

Another rural farmer described a similar situation: she would like to scale up beyond the US $\$ 20,000$ limit into licensed production, but she lacks the capital to build her own facility and the few available buildings in her small community would be very expensive to retrofit. She explained, "We'd have to leave and go to a different town... being rural, you know... those facilities are generally urban."

\section{A gritourism}

As mentioned earlier, farmers can now make products that are an easier sell for "agritourists." The state of O regon is actively promoting agritourism as an economic development opportunity for rural communities and, more broadly, a way to strengthen rural-urban connections (Lurie \& Brekken, 2017). O ne farmer in a coastal community said that the FD ML had made it possible to make small batches of value-added products to sell as souvenirs or gifts, not groceries. His local farmers market, he said, "has a lot of tourists. Tourists don't want to buy plant starts or bouquets, but they love to take jam home to A unt Martha in Minneapolis. So it was a great outlet. ... Half of the jams and jellies that I sell are to tourists."
Community benefits

FD ML can generate economic benefits not only for farmers but for their communities. O ne market manager noted that, "every product that can be created in a community and sold at the market or a farm stand or CSA is one more thing that can actually be bought there, in rural communities that lack grocery stores." And most rural stores, she continued, "aren't going to have these jams, pickles, dried beans and grains." These local products and businesses are also "creating a community where people want to be ... which is far more significant than the economic development," said one farmer in an isolated part of O regon.

F ood Security (U nanticipated)

Because of our target interviewees and questions, most benefits raised were about farmers, as expected. However, increasing food securityspecifically by making nutritious foods more available and affordable in isolated or low-income areas - was mentioned in our initial focus group and in four interviews as a potential benefit of the FD ML. Value-added foods are not, by definition, nutritious, but the types of food farmers are making under the FD ML contain whole foods, such as jams, pickles, dried beans, and grains.

A manager of a market in a low-income area between two more affluent cities said, "Y ou have two ends of the spectrum... If you are in a more affluent neighborhood, it's more of the foodie side of it, that they like the idea and they like having local fresh options, whereas on our side of it it's just having more options." Similarly, as noted in the test marketing section above, a farmer in a lowincome rural area is keeping his costs low so his community can afford his products. Another farmer said, "Where we're at, we're in what they call a food desert, you know, it's pretty sparse out there."

In summary, we found evidence that the cottage foods provision of the Farm Direct Marketing Bill is working as advocates had hoped, in both urban and rural areas of Oregon. While the full extent of these impacts is beyond the scope of this paper, and potential long-term benefits (e.g., farm viability and rural economic development) will take time to materialize, we expect that more farmers will take advantage of this opportunity. 
W hat barriers do farmers face when using the FD M L ? H ow could it be improved?

In our interviews, we asked whether there were any barriers to using the law and then asked, separately, how the law might be improved. Answers to these two questions, not unexpectedly, converged enough that we present these results together. In stark contrast to benefits, far fewer barriers were mentioned by farmers and market managers. In fact, three market managers and five farmers named no barriers or improvements at all, even when prompted two or more times. Market managers responded with their own opinions and also with what they had heard from their farmer vendors.

The barriers and improvements that were mentioned (Table 4) fall into two basic themes related to the law's operational feasibility: unclear rules and too many restrictions. We discuss each of these barriers and improvements below. As we discuss later in this paper, the list of suggested improvements includes those possible now and those requiring changes to the administrative rules, the interpretation of those rules, or the law itself.

Improving Clarity and Information

The barrier most often mentioned, by four market managers and two farmers, was not about the law itself but about a real or perceived lack of clear information about the rules. This clearly echoes the concerns expressed when the law was passed, that the many qualifications made the exact requirements difficult to communicate to farmers and consumers. Farmers, for example, said that what counted as "approved" in "approved recipe" was not clear.

Interestingly, while the market managers also sought clarity on aspects of the law, they were equally concerned that farmers were not finding or using existing information. For example, one manager said, "the education, the resources, and the materials are out there," for example, from O SU Extension and the ODA. However, he continued, "I think bandwidth and capacity on a farm is a barrier."

Parallel to this, clarifying requirements and providing more information were together the most cited suggested improvements, named by two farmers and ten market managers. O ne farmer asked for the rules to be provided in a format "simpler than the legal version," referring to resources posted on the OD A website; market managers echoed this and also asked for Spanishlanguage versions in addition to English. Another farmer asked for clarification about a specific category of products that he believed the rules allowed but his county health inspector did not. Managers also asked for clarity about products that the rules

Table 4. Barriers and Suggested Improvements $(\mathrm{N}=42)$

\begin{tabular}{lllcc}
\hline Barriers & Suggested Improvements & $\begin{array}{c}\text { Farmer } \\
(\mathrm{n}=18)\end{array}$ & $\begin{array}{c}\text { Market Manager } \\
(\mathrm{n}=24)\end{array}$ & \multicolumn{1}{c}{ Total } \\
\hline $\begin{array}{l}\text { Unclear requirements and more } \\
\text { information needed }\end{array}$ & $2(11 \%)$ & $4(17 \%)$ & $6(14 \%)$ \\
\hline & Clarify rules; provide more information & $2(11 \%)$ & $10(42 \%)$ & $12(29 \%)$ \\
\hline & Allow more product types & $3(17 \%)$ & $1(4 \%)$ & $4(10 \%)$ \\
\cline { 2 - 5 } & Allow more market channels & $3(17 \%)$ & 0 & $3(7 \%)$ \\
\cline { 2 - 5 } Exemptions are too narrow & Expand ingredients allowed & $2(11 \%)$ & 0 & $2(5 \%)$ \\
\cline { 2 - 5 } & Raise annual sales revenue cap & $1(6 \%)$ & 0 & $1(2 \%)$ \\
\hline Labeling and recordkeeping & & $2(11 \%)$ & 0 & $2(5 \%)$ \\
\hline requirements & & 0 & $1(4 \%)$ & $1(2 \%)$ \\
\hline Approved recipe requirement & & $1(6 \%)$ & $2(8 \%)$ & $3(7 \%)$ \\
\hline Liability insurance* & & &
\end{tabular}

* Liability insurance is not mandated by the Farm Direct Marketing Law (FDML) but is required by some markets. 
did not directly name but might actually allow, for example, frozen fruit, fruit vinegars, and kombucha. As one manager said, "None of us are looking for a way out of following the rules.... We just want it to be clear and science-based too."

Managers also asked for more food safety education for farmers, for example on $\mathrm{pH}$ testing, sources of approved recipes, and food safety practices relevant to these products and their scale of production. O ne manager said, "Hand in hand with this kind of policy, states need to make sure there is adequate education for farmers." Another noted that food preservation knowledge had "skipped a couple generations, so you gotta bone up on your skills. ... Their mothers didn't do it, and maybe their grandmothers didn't do it, and maybe they didn't learn."

Finally, six market managers and one farmer also suggested that more information about the law and its requirements be made available to the public. Managers want the public to know that FD ML products are both safe and legal. The farmer asserted that if the public knew the rules, they would be less likely to buy from farmers who broke those rules. However, as one manager pointed out, consumers are much more likely to understand "farm direct" as a concept versus the FD ML cottage food provision as a specific legal exemption: "I think it's hard from a consumer perspective to know that those pickles are something that wouldn't be available five years ago."

\section{E x panding the FD M L E x emption} Other suggested improvements fall under the general category of "expand the exemption." O ne farmer said FD ML "is a step in the right direction.... I'd like to see those restrictions loosened a bit more." Their specific objections mirror the concerns raised at the time of passage, and most of their suggestions would require changes in the rules or the law. None of these suggestions were particularly surprising, given that the farmers we interviewed have already seen some success with these products and would like additional opportunities.

Three farmers wanted to make a broader range of products, from a pesto made of garlic greens or scapes that would not meet the acidity requirements of raw milk and cheese. Three farmers also wanted to expand to more market channels, such as retail stores, restaurants, and through other farmers by consignment. Two farmers wanted to expand allowed ingredients, such as buying ingredients from a farmer at the same market with extra berries but no time to make jam. O nly one farmer wanted to raise the sales cap.

Some farmers and market managers also felt that the labeling, recordkeeping, and approved recipe requirements were too strict. For farmers, labeling and recordkeeping were doable but an extra "hassle factor." As one farmer said, "it's not a big deal, but still, it takes time." These objections to fairly simple requirements echoed what a market manager said she heard from farmers about having to use approved recipes. She remarked, "I think sometimes that can feel like a barrier, when in reality, I don't really know that it is so much, but... I think there's a perception that with [FDML] the concept is removing some of the rules... Then to find out that there's certain t's to cross and i's to dot...." Part of this, she observed, was that farmers are often fiercely independent business owners and, "feel fortunate to have an opportunity not to be told what to do." Ultimately, she said, even if a requirement is not truly a barrier in practice, "it can be a perceived barrier," which she believed was "just as strong as [being] a barrier."

Finally, one farmer and two managers discussed the need for liability insurance, which is not required by the law but rather by many markets, whether vendors sell processed or only fresh products. The two managers who mentioned this had heard it from a few farmers but doubted it was a common problem due to the relatively low cost of a policy and the risk management value.

In summary, farmers are processing and selling a wide variety of products under the FD ML exemption. Based on the available data, no foodborne illness outbreaks have been linked to products made and sold under the law. Farmers and market managers described a range of benefits- primarily for farmers, but also for communities. Most of these benefits match the "pro" arguments during the passage of the law. Farmers and market managers identified barriers and suggested changes related to policy, education, and information. 


\section{Discussion}

Our study explored early outcomes of O regon's Farm D irect Marketing Law during its first five years. As such, our study provides a rare look at a cottage food law in practice, from the perspective of people actually using it. We provide much needed, albeit preliminary, empirical evidence about the farm- and community-level benefits, food safety outcomes, and operational feasibility of cottage food laws.

It appears that the cottage food portion of the FD ML is working well so far. In summary, we found that many of the anticipated benefits and several that were unanticipated had occurred for at least some farmers and may be happening in some communities. This aligns with the purpose of the law and broadens its relevance.

The suggestions for improvements to the law echo some recommendations made by Leamy (2017) in his comparison of cottage food laws across the country and his survey of cottage food producers. For example, some interviewees proposed raising or removing the sales cap of US $\$ 20,000$ for producer-processed products. Leamy reasons that the limit on sales is practically imposed by the amount of product that can be made in a home kitchen. More than half of the states with cottage food laws have no limit on sales. While this might benefit farmers and their communities, the political feasibility of this in Oregon is uncertain, due to ongoing concern about foodborne illness. Licensed food processors might also object to increased competition from businesses that would be less regulated and have lower compliance costs.

O ther suggestions for expanding the FD ML could be more politically feasible because they more closely align with the goals of the law. For example, expanding the exemption to allow farmers to use produce from neighboring farmers could potentially expand the benefits of the law without compromising food safety. That assumes, however, that the farm doing the sourcing knows and trusts the neighbor's on-farm food safety practices.

O ur study also revealed that existing education and information resources have been useful but need to reach a broader audience and address additional questions and topics. As of this writing,
O SU Extension and the ODA have responded to this with new workshops and publications (e.g., Runkel, G win, \& Streit, 2018). To reach a broader audience, educational program design and outreach is being done by these entities in partnership with the state farmers market association, other community food system organizations, and farmers' own social and business networks.

If the range of benefits our interviewees identified are occurring more broadly for other farmers and communities around the state, and if those benefits grow over time, the FD ML could have important long-term impacts on several levels, as discussed earlier. First, it could improve the longterm economic viability of small to mid-scale farms across the state. Second, this type and scale of food production and marketing could, more broadly, contribute to economic development and rural wealth creation. This can also happen in conjunction with other activities such as agritourism (Lurie \& Brekken, 2017). Third, if the law actually increases access to value-added foods that are nutritious, the law could contribute to community food security. At the same time, food safety practices that are appropriate to the scale and type of these enterprises will be necessary to protect consumers from foodborne illness (Buckley, 2015; Condra, 2013; DeLind \& Howard, 2008; Harrison, Critzer, \& Harrison, 2016; Leamy, 2017; Yapp \& Fairman, 2006).

Achieving the long-term potential of FD ML for farms and communities requires action at different levels by different actors. At the most basic level, this begins with the market transaction: more farmers making and selling more products, and more consumers knowing about and purchasing these products. Y et, more is needed than farm entrepreneurship and consumer demand. O utreach and education have already expanded, including a focus on best practices related to food safety for the scale and type of farm, processing, and product. As noted already, additional research is needed to validate our initial suggestions about the benefits of the FD ML while at the same time continuing to monitor for foodborne illness outbreaks or other negative outcomes. Longer-term empirical evidence, if positive, could allow advocates to push for regulatory or legislative changes to the existing 
law and rules. Yet, advocates can also pursue public investment in commercial kitchens and business incubation services, if demand for these were sufficient, to support farmers and other small businesses interested in larger-scale, licensed production. Finally, rural communities and food security advocates also have a role to play if the FD ML is conceived more broadly to achieve rural food security goals.

The success of such efforts will depend on the continued importance of the farm direct marketing sector to O regonians, which was strongly signaled in 2011 by the passage of FD ML. This holds true today; as a high-level OD A employee who typically focused on export markets and larger-scale agriculture said recently, "We have so many advocates and so much interest by people for the movement, sale, and purchase of $O$ regon food and agricultural products, that I would expect direct farm marketing to significantly expand in the near and longterm future" (ODA, 2016). Farmers and other local food system stakeholders, building on this influence, can use this study and the growing body of applied research about 0 regon's local food and direct market farming sector (e.g., Brekken, Parks, \& Lundgren, 2017; Horst \& G win, 2018; Lurie \& Brekken, 2017; Rahe, Van D is, Weiland, \& G win, 2017; Trant, Brekken, Lev, \& G win, 2018) to advocate for supportive public policy, from laws and regulations to the allocation of public resources.

In the course of our research, we heard several stories that support the idea that FD ML was not simply a one-time win. For example, one market manager who participated in our group discussion pointed to a new seat at the table where regulatory agencies make critical administrative decisions:

In 2005, there was a reallocation of the license fees from ODA. We were not at the table, and we were hurt very badly. Small farms, farm direct marketing people ... got hit with higher fees ... [which] started a bad cycle in the regulatory relationship. This year, I'm on the food safety advisory committee. At the first mention of the new fees [in 2017], I walked up to the new Food Safety director and said we weren't at the table last time and got screwed, so can we be at the table, and now I'm there and have had a voice.

The FD ML also provided a protective framework when new FSMA regulations appeared to have the potential to undo the exemptions for FD ML products ( $\mathrm{G}$ win \& Landis, 2017). The vastly improved relationship between the state agricultural agency and farm direct marketing advocates was critical to maintaining the FD ML in the face of pressure to tighten food safety regulations.

\section{Conclusion}

We conclude this paper by stepping back to consider O regon's Farm D irect Marketing Law as a whole. FD ML has achieved what it was designed to do: resolve significant regulatory ambiguity for direct market sales of fresh produce and create a cottage food opportunity for $\mathrm{O}$ regon farmers. While the cottage foods provision created space for farmers to develop new product lines and income streams, the other elements of the FD ML were essential to the continued growth of farm direct marketing in O regon because they prevented an anticipated ex pansion of regulations on the farm direct marketing sector by clarifying existing food safety laws. Without those provisions, farm direct sales might have been significantly curtailed in O regon; instead, they have continued to grow.

Although O regon has a large number of farms involved in direct marketing, a small number were predicted to take advantage of the FD ML opportunities, and it was understood that it would take some time before consumers began to see producer-processed products at the market (Brekken, 2012). Similarly, it will take time for benefits to scale up to more farmers and communities. As one manager said, "what's allowed under Farm Direct ... that was just what happened a hundred years ago, people made sauerkraut and they sold it at markets [laughs], we're kind of reinventing a wheel in a way that I think it might take some time for it to actually settle into a really valuable and viable opportunity for farmers."

Direct sales of small batches of value-added foods are unlikely, on their own, to guarantee a farm's long-term success, community food 
security, or rural economic development. However, these innovative, entrepreneurial farmers and their products are key ingredients in the recipe for longterm viability for farms and their communities.

\section{Acknowledgements}

We are grateful to our initial focus group partici- pants who helped us design this project. We are also grateful to the farmers and market managers who took time out of their busy market seasons to speak with us. Finally, we appreciate the three anonymous JAFSCD reviewers: their detailed and useful guidance helped us significantly strengthen this paper.

\section{References}

Alonso, A. D ., \& O 'Neill, M. A. (2011). Interest in maximisation and value-added produce: a preliminary study from Chilton County, Alabama. British F ood Journal, 113(5), 637-655. https:/ / doi.org/ 10.1108/ 00070701111131746

Alonso, A. D . (2011). Farmers' involvement in value-added produce: The case of Alabama growers. British F ood Journal, 113(2), 187-204. https:/ / doi.org/ 10.1108/ 00070701111105295

Alonso, A. D ., \& Northcote, J. (2013). Investigating farmers' involvement in value-added activities: A preliminary study from Australia. British F ood Journal, 115(10), 1407-1427. https:/ / doi.org/ 10.1108/ BFJ-04-2011-0104

Antle, J. M. (2000). No such thing as a free safe lunch: The cost of food safety regulation in the meat industry. A merican Journal of A griaultural E conomics, 82(2), 310-322. https:/ / doi.org/ 10.1111/ 0002-9092.00027

Bauer, K. (2011, February 9). Farm bulletin call to action. G ood Stuff N W . Retrieved from http:/ / www.goodstuffnw.com/ 2011/ 02/ farm-bulletin-call-to-action.html

Bernard, H. R. (2011). Research methods in anthropology: Q ualitative and quantitative approaches (5 $5^{\text {th }}$ Ed.). Lanham, MD : AltaMira Press.

Boys, K. A., Ollinger, M., \& Geyer, L. L. (2015). The Food Safety Modernization Act: Implications for U.S. small scale farms. A merican Journal of $\mathrm{L}$ aw and M edicine, 41(2-3), 395-405. https:/ / doi.org/ 10.1177/ 0098858815591524

Brekken, C. A. (2012). Can we have our (safe and local) cake and eat it too? O regon re-crafts food safety regulations for farm direct marketed foods. Journal of A griculture, Food Systems, and Community D evelopment, 3(2), 95-108. https:/ / doi.org/ 10.5304/ jafscd.2013.032.003

Brekken, C. A., Parks, M., \& Lundgren, M. (2017). O regon producer and consumer engagement in regional food network: Motivations and future opportunities. Journal of A griaulture, F ood Systems, and C ommunity D evelopment, 7(4), 125. https:/ / doi.org/ 10.5304/ jafscd.2017.074.008

Buckley, J. A. (2015). Food safety regulation and small processing: A case study of interactions between processors and inspectors. Food Policy, 51, 74-82. https:/ / doi.org/ 10.1016/j.foodpol.2014.12.009

Centers for Disease Control and Prevention (CD C). (2016). Foodborne O utbreak O nline D atabase (FO OD Tool). Retrieved August 25, 2016, from https:/ / wwwn.cdc.gov/ foodborneoutbreaks/ D efault.aspx (Search results on file with authors.)

Center for Science in the Public Interest (2015). A ll over the map: A 10-year review of state outbreak reporting. Retrieved from https:/ / cspinet.org/ sites/ default/ files/ attachment/ all-over-the-map-report-2015.pdf

Clayton, D . A., G riffith, C. J., Price, P., \& Peters, A. C. (2002). Food handlers' beliefs and self-reported practices. International Journal of E nvironmental H ealth Research 12(1), 25-39. https:/ / doi.org/ 10.1080/ 09603120120110031

Condra, A. (2013). Cottage Food Laws in the United States. H arvard F ood L aw and Policy Clinic. Retrieved from https:/ / www.chlpi.org/ wp-content/ uploads/ 2013/ 12/ FINAL_Cottage-Food-Laws-Report_2013.pdf

DeLind, L. B. \& Howard, P. H. (2008). Safe at any scale? Food scares, food regulation, and scaled alternatives. A griculture and $\mathrm{H}$ uman $\mathrm{V}$ alues 25(3), 301-317. https:// doi.org/ 10.1007/ s10460-007-9112-y

Fairman, R., \& Y app, C. (2005). Enforced self-regulation, prescription, and conceptions of compliance within small businesses: The impact of enforcement. L aw and Policy, 27(4), 491-519. https:/ / doi.org/ 10.1111/ j.14679930.2005.00209.x

Gwin, L. (2018). O regon's home baking bill: Residential kitchen ex œption for baked goods and confectionary items (\#EM 9192). Corvallis, OR: Oregon State University. 
Journal of Agriculture, Food Systems, and Community Development

ISSN: 2152-0801 online

https:/ / www.foodsystemsjournal.org

Gwin, L., \& Landis, R. (2017). Farm D irect and F SMA : W hy 0 regon's pioneering farm direct law is (mostly) not affected by the federal F ood Safety M odernization A ct. OSU Small Farms Technical Report. Corvallis: Extension Small Farms Program, O regon State University. Retrieved from http:// smallfarms.oregonstate.edu/ sites/ default/ files/ small-farms-techreport/ farm direct and fsma.pdf

Gwin, L., \& McCann, N. (2017). Use it or lose it: Local food, regional processing and the perils of unused capacity. In Federal Reserve Bank of St. Louis, Board of G overnors of the Federal Reserve System, and the U.S. D epartment of Agriculture (Eds.), H arvesting O pportunity: The Power of Regional F ood System Investments to Transform Communities (pp. 151-171). Retrieved from https:/ / www.stlouisfed.org/ community-development/ publications/ / media/ Files/ PDFs/Community-D evelopment/ Harvesting-O pportunity/ Harvesting O pportunity.pdf?la=en\#page=151

Harrison, J. A., Critzer, F. J., \& Harrison, M. A. (2016). Regulatory and food safety knowledge gaps associated with small and very small food businesses as identified by regulators and food safety educators-implications for food safety training. F ood Protection Trends, 36 (6), 420-427.

Horst, M. \& G win, L. (2018). Land access for direct market farmers in O regon, USA. L and U se Policy, 75, 594-611. https:// doi.org/ 10.1016/ j.landusepol.2018.01.018

Jablonski, B., Hendrickson, M., Vogel, S., \& Schmit, T. (2017). Local and regional food systems driving rural economic development. In A. D umont, D. D avis, J. Wascalus, T. Cheeks-Wilson, J. Barham, \& D. Topp (Eds.), H arvesting opportunity: The power of regional food system investments to transform communities (pp. 57-77). St. Louis, MO: Federal Reserve Bank of St. Louis, Board of Governors of the Federal Reserve System, \& the U.S. Department of Agriculture. Retrieved from https:// www.stlouisfed.org/ / media/ Files/ PD Fs/ Community-D evelopment/ HarvestingOpportunity/ Harvesting O pportunity.pdf?la=en

Johnson, D . B., Q uinn, E., Sitaker, M., Ammerman, A., Byker, C., D ean, W. ... Sharkey, J. (2014.) D eveloping an agenda for research about policies to improve access to healthy foods in rural communities: a concept mapping study. BM C Public H ealth 14, 592. https:/ / doi.org/ 10.1186/ 1471-2458-14-592

Leamy, N. (2017). C an you mak e your cake and sell it too? C onsidering public value in private food production (Master's thesis). Cambridge, MA: Harvard University. Retrieved from https:// books.google.com/books/about/Can_You Make Your Cake and Sell it Too.html?id=rrmaswEACAAI

Lies, M. (2011, February 11). Food safety exemption bill moves to floor. Capital Press. Retrieved from http:/ / www.capitalpress.com/ content/ ml-food-safety-bill-021111

Love, D . (2011, April 19). States advocate for legislation and regulation to support home-based micro-processing. Farmers Mark et Coalition. Retrieved from https:/ / farmersmarketcoalition.org/ states-advocate-for-legislation-andregulation-to-support-home-based-micro-processing/

Lurie, S., \& Brekken, C. A. (2017). The role of local agriculture in the new natural resource economy (NNRE) for rural economic development. Renewable A griculture and F ood Systems, 1-11. https:/ / doi.org/ 10.1017/ S174217051700062X

Mensah, L. D ., \& Julien, D . (2011). Implementation of food safety management systems in the UK. F ood Control, 22 (8), 1216-1225. https:/ / doi.org/ 10.1016/ j.foodcont.2011.01.021

Miller, S. R. (2015). A coordinated approach to food safety and land use law at the urban fringe. A merican Journal of $\mathrm{L}$ aw \& M edicine, 41(2-3), 422-446. https:/ / doi.org/ 10.1177/ 0098858815591526

National Sustainable Agriculture Coalition. (2016). Understanding FD A's FSMA rule for produce farms. Retrieved from http:/ / sustainableagriculture.net/ wp-content/ uploads/ 2008/ 08/ FSMA-PRO DUCE-RULE-FINAL.pdf

O regon D epartment of Agriculture (OD A) (2016, D ecember 21). Local markets a vital part of O regon agriculture. O regon D epartment of Agriculture News. Retrieved from http:/ / odanews.wpengine.com/ local-markets-a-vitalpart-of-oregon-agriculture/

O regon Health Authority (OHA) (n.d.). Foodborne disease and gastroenteritis outbreaks, O regon Public Health Division. Retrieved from http:/ / www.oregon.gov/ oha/ PH/ DISEASE SCO NDITIONS/ COMMUNICABLED ISEASE/ O UTBREAKS/ G ASTROENTERITIS/ Pages/ index.aspx 
O regon Revised Statute $\S$ 616.683. (2017). Text available at https:/ / www.oregonlaws.org/ ors/ 616.683

O regon Senate Bill 320 (Enrolled). (2015). Text available at

https:/ / olis.leg.state.or.us/ liz/ 2015R1/ D ownloads/ MeasureD ocument/ SB320/ Enrolled

O regonian, The/ O regonLive. (n.d.). Y our G overnment, 2011 Session, House Bill 2336. Retrieved from https:// gov.oregonlive.com/ bill/ 2011/ HB2336/

Parker, J. S., D eNiro, J., Ivey, M. L., \& D oohan, D . (2016). Are small and medium scale produce farms inherent food safety risks? Journal of Rural Studies, 44, 250-260. https:/ / doi.org/ 10.1016/ j.jrurstud.2016.02.005

Rahe, M., Van D is, K., Weiland, J., \& G win, L. (2017). E conomic impact of local food producers in C entral 0 regon. Corvallis: O regon State University. Retrieved from https:/ / appliedecon.oregonstate.edu/ sites/agscid7/ files/ economicimpact_localfoods_centraloregon.pdf

Robson, C. (2011). Real world research: A resource for users of social research methods in applied settings (3rd ed.). Hoboken, NJ: John Wiley \& Sons.

Runkel, S., G win, L., Streit, L. (2018). 0 regon's Farm D irect Mark eting L aw: Producer-processed valueadded products. Corvallis: O regon State University.

Sorte, B. \& Rahe, M. (2015). O regon agriculture, food and fiber: An economic analysis. O regon State University Extension Service. Retrieved from http:// agsci.oregonstate.edu/ sites/ agsci.oregonstate.edu/ files/ oregon agriculture 2015.pdf

Stearns, D. W. (2010). On (cr)edibility: Why food in the United States may never be safe. Stanford L aw \& Policy Review, 21(2), 245-275.

Tarr, N. W. (2011). Food entrepreneurs and food safety regulation. Journal of F ood L aw and Policy, 7(1), 35-68.

Terry, L. (2011, February 16). Rules for O regon farmers markets, formerly homegrown, could soon be law. The 0 regonian. Retrieved from http:/ / www.oregonlive.com/ health/ index.ssf/ 2011/ 02/ rules for_oregon farmers marke.html

Thomas, C. (2015, June 10). O regon legislature passes home baking bill. Public News Service. Retrieved from https:// www.publicnewsservice.org/ 2015-06-10/ hunger-food-nutrition/ oregon-legislature-passes-home-bakingbill/ a46617-1

Trant, L., Brekken, C. A., Lev, L., \& G win, L. (2018). Implications of the 2016 O regon minimum wage increase for direct market farmers, farmworkers, and communities. Sustainability, 10(2), 370. https:/ / doi.org/ 10.3390/ su10020370

U.S. D epartment of Agriculture, National Agricultural Statistics Service [USD A-NASS]. (n.d.). 2015 Local Food Marketing Practices Survey Quick Stats: O regon. Retrieved from https:/ / quickstats.nass.usda.gov/ results/ F56FD 130-F71A-3904-9490-E7610683D FE0

USD A-NASS. (2017). 2017 State Agricultural O verview: O regon. Retrieved from https:// www.nass.usda.gov/ Q uick Stats/Ag_Overview/ stateO verview.php?state=oregon

USD A-NASS. (2016, D ecember). D irect F arm Sales of F ood: Results from the $2015 \mathrm{~L}$ ocal F ood M ark eting Practices Survey. Retrieved from https:/ / www.agcensus.usda.gov/ Publications/ 2012/O Online_Resources/Highlights/Local_Food/ LocalFoodsMarketingPractices Highlights.pdf

U.S. Food and D rug Administration. (2017). Food Code 2017. Retrieved from https:// www.fda.gov/ Food/G uidanceRegulation/ RetailFoodProtection/ FoodCode/ ucm595139.htm

Worosz, M. R., Knight, A. J., Harris, C. K., \& Conner, D . S. (2008). Barriers to entry into the specialty red meat sector: The role of food safety regulation. Southern Rural Sociology, 23(1), 170-207. Retrieved from http:/ / journalofruralsocialsciences.org/ pages/ Articles/ SRS\%202008\%2023/ 1/ SRS\%202008\%2023\%201\%20170207.pdf

Yapp, C., \& Fairman, R. (2006). Factors affecting food safety compliance within small and medium-sized enterprises: Implications for regulatory and enforcement strategies. Food Control, 17(1), 42-51. https:/ / doi.org/ 10.1016/ j.foodcont.2004.08.007

Young, I., Thaivalappil, A., Reimer, D ., \& G reig, J. (2017). Food safety at farmers markets: A knowledge synthesis of published research. Journal of F ood Protection, 80(12), 2033-2047. https:/ / doi.org/ 10.4315/ 0362-028X.JFP-17-193 